\title{
PENYULUHAN ANEMIA DEFESIENSI ZAT BESI PADA IBU HAMIL DI PUSKESMAS GARUDA
}

\author{
Liva Maita, Ayu Nopita Sari, Wan NisaDestriana \\ Prodi Kebidanan STIKes Hang Tuah Pekanbaru
}

\begin{abstract}
Abstrack
Maternal mortality rate (MMR) is an indicator of the success of health services in a country. Maternal death can occur due to several reasons, including anemia. Research shows that the maternal mortality rate is $70 \%$ of the women who suffer from anemia and $19.7 \%$ of those who are not anemic. The aim of this service is to increase public understanding of anemia, especially iron deficiency anemia in pregnant women. This activity was held on August 24, 2018 at the Garuda Public Health Center, which was attended by 18 pregnant women and the community using counseling methods. This activity provides the results of the visitor understanding the Anemia material delivered by the speaker. Visitors who attended were enthusiastic in participating in the counseling and there was a discussion between the presenter and visitors. Participants actively asked questions about the problems they had experienced around anemia. It is hoped that the Puskesmas will regularly provide health information to the public, especially the problems that are often experienced by pregnant women.
\end{abstract}

Key Word: Education, anemia, iron deficiency

\begin{abstract}
Abstrak
Angka kematian ibu (AKI) merupakan salah satu indikator keberhasilan layanan kesehatan di suatu negara. Kematian ibu dapat terjadi karena beberapa sebab, diantara karena anemia . Penelitian menunjukkan bahwa angka kematian ibu adalah $70 \%$ dari ibu yang menderita anemia dan 19,7\% mereka yang non- anemia. Tujuan Pengabdian untuk meningkatkan pehaman masayarakat mengenai anemia terkhusus nya anemia defesiensi zat besi pada ibu hamil. Kegiatan ini dilaksakanakan pada tanggal 24 Agustus 2018 di Puskesmas Garuda yang diikuti oleh 18 orang Ibu hamil dan Masyarakat dengan metode penyuluhan. Kegiatan ini memberikan hasil Pengunjung memahami materi Anemia yang disampaikan oleh pemateri. Pengunjung yang hadir antusias dalam mengikuti penyuluhan dan Terjadi diskusi antara penyaji dan pengunjung. Peserta aktif bertanya mengungkapkan masalah yan dialaminya seputar anemia. Kepada Pihak Puskesmas diharapkan rutin untuk memberikan informasi kesehatan kepada masyarakat terutama permsalahan yang sering dialami oleh ibu hamil.
\end{abstract}

Key Word : Penyuluhan, Anemia, Defisiensi zat besi 


\section{Pendahuluan}

Angka kematian ibu (AKI) merupakan salah satu indikator keberhasilan layanan kesehatan di suatu negara. Kematian ibu dapat terjadi karena beberapa sebab, diantara karena anemia . Penelitian menunjukkan bahwa angka kematian ibu adalah $70 \%$ dari ibu yang menderita anemia dan $19,7 \%$ mereka yang non- anemia. Kematian ibu 15-20 $\%$ secara langsang dan tidak langsung berhugan dengan anemia. Anemia pada kehamilan juga berhubngan dengan angka kesakitan ibu. Anemia defisiensi zat besi merupakan penyebeb utama anemia pada ibu hamil.dibandingkan dengan defesiensi zat gizi lainnya. Oleh karena itu anemia sering di identikkan dengan anemia kekurangan zat besi.

Di Amerika Serikat orang yang mengalami anemia sebanyak 2\%- $10 \%$. Sedangkan di negara berkembang memiliki angka yang lebih tinggi (Atikah,2011). Di Indonesia sekitar 70\% ibu hamil menderita anemia dan didominasi oleh anemia defesiensi zat besi. Anemia defesiensi zat bei merupakan masalah yang paling lazim di duni adan menjangkiti 600 juta manusia dengan frekuensi yang masih cukup tinggi.

Badan kesehatan dunia ( World Health Organization / WHO) melaporkan bahwa pravelensi ibu hamil yang mengalami defesinsi besi sekita 35$75 \%$ serta semakin meningkat seriirng dengan pertambahan usia kehamilan. Sedangkan di Indonesia Pravelensi anemia masih tinggi sekitar 40,1\%. Mengingat besarnya dampak buruk dari anemia defesiensi zat besi pada wanita hamil dan janin oleh karena itu perlu perhatian terhadap masalah ini.

Di Puskesmas Garuda Banyak ibu hamil yang belum mengetahui tentang anemia defisiensi zat besi. Oleh sebab itu diperlukan penyuluhan tentang anema defisiensi zat besi.

\section{Perumusan Masalah}

Anemia sebagai penyebab meninkannya angka kematian ibu masih menjadi perhatian penting dan diberikan tanggapan khusus agar menurunkan status angka kematian dan angka kesakita ibu akibat defesiensi zat besi. Untuk itu perlunya pengetahuan lebih seputar: Anemia secara umum, Anemia pada ibu hamil dan penyebabnya, Pengobatan anemia dan Pencegahan anemia

\section{Tujuan Kegiatan}

Untuk meningkatkan pehaman masayarakat mengenai anemia terkhusus nya anemia defesiensi zat besi pada ibu hamil.

\section{Metode Kegiatan}


Kegiatan ini dilaksakanakan pada tanggal 24 Agustus 2018 di Puskesmas Garuda yang diikuti oleh 18 orang Ibu hamil dan Masyarakat. Pengabdian ini dilakukan dengan cara memberikan penyuluhan mengenai anemia defisiensi zat besi

\section{Hasil}

Kegiatan yang dilakukan dalam penyuluhan ini dilaksanakan dalam beberapa tahap yang diawali dengan penyampaian materi terlebih dahulu, kemudian setelah diberikan materi melakukan seksi tanya jawab serta diskusi.

Kegiatan ini memberikan hasil Pengunjung memahami materi Anemia yang disampaikan oleh pemateri. Pengunjung yang hadir antusias dalam mengikuti penyuluhan dan Terjadi diskusi antara penyaji dan pengunjung. Peserta aktif bertanya mengungkapkan masalah yan dialaminya seputar anemia.

\section{Kesimpulan}

Kegiatan penyuluhan tentang
hipertensi yang dilaksanakan di
Puskesmas Garuda Kota Pekanbaru
berjalan dengan baik dan sesuai
rencana. Hal ini terbukti dari
antusiasme para Pengunjung saat
penyuluhan berlangsung. Para peserta
penyuluhan benar-benar memperhatikan

dan mendengarkan dengan baik tentang materi yang disampaikan. Saat membuka seksi tanya jawab peserta sangat antusias untuk menjawab maupun bertanya.

\section{Saran}

Kepada Pihak Puskesmas diharapkan rutin untuk memberikan informasi kesehatan kepada masyarakat terutama permsalahan yang sering dialami oleh ibu hamil.

\section{Dafar Pustaka}

Departemen Kesehatan RI. Profil Kesehatan Indonesia tahun 2010. Jakarta: Departemen Kesehatan RI; 2010

Departemen Gizi dan Kesehatan Masyarakat Fakultas Kesehatan Masyarakat Universitas

Indonesia. Gizi dan Kesehatan Masyarakat. Jakarta: Rajagrafindo Persada; 2008

Laksmi, PW. Dkk. Penyakit-Penyakit

Pada Kehamilan : Peran Seorang

Internis. Jakarta: Pusat Penerbitan

Ilmu Penyakit Dalam Fakultas

Kedokteran Universitas Indonesia; 2008

Tarwoto. Wasnidar. Buku Saku Anemia Pada Ibu Hamil Konsep dan 
Penatalaksanan. Jakarta: Trans

Info Media; 2009
Proverawati, A. Anemia dan Anemia

Kehamilan. Yogyakarta: 